\title{
Rевевкин Автісі: : Squash from tamarind pulp by blending with mango pulp
}

\section{口. KIRANMAI, K. UMA MAHESWARI, B. VIMALA AND G. SUDHA DEVI}

Article Chronicle: Received : 17.07.2017;

Accepted : 01.08 .2017

KEY WoRds : Tamarind, Mango, Squash, Overall Acceptability, Storage
SUMMARY : A study was conducted on development of squash with tamarind by blending with mango pulp at different levels $(10 \%, 20 \%$ and $30 \%)$ and different sugar concentrates. all the treatments were kept for three months storage period to evaluate their storage stability. During the storage period all the treatments were evaluated for the physico-chemical, microbial and sensory quality. The results revealed that among all the treatments highest acceptability observed in squash prepared with $80 \%$ tamarind pulp and 20\% mango pulp $\left(\mathrm{T}_{6}\right)$ during the storage period. No microbial growth was observed in all the treatments. The products were stored without any deterioration in physico-chemical, sensory quality and microbial count upto 3 months of storage period.

How to cite this article : Kiranmai, E., Maheswari, K. Uma, Vimala, B. and Devi, G. Sudha(2017). Squash from tamarind pulp by blending with mango pulp. Agric. Update, 12(TECHSEAR-6) : 1660-1665; DOI: 10.15740/ HAS/AU/12. TECHSEAR(6)2017/1660-1665.
Author for correspondence :

\section{E. KIRANMAI}

Indian Institute of Millets Research, HYDERABAD (TELANGANA) INDIA 